\title{
Comparison of the effect of two drugs paracetamol with intravenous ibuprofen in patent ductus arteriosus treatment
}

\author{
Mehrdad Mirzarahimi ${ }^{1}$, Ramin Emamzadeghan ${ }^{1}$, Afsaneh Enteshari Moghaddam²*, \\ Narges Falsafi ${ }^{3}$
}

${ }^{1}$ Department of Pediatrics, ${ }^{2}$ Department of Internal Medicine, School of Medicine, Ardabil University of Medical Science, Ardabil, Iran

${ }^{3}$ School of Medicine, Ardabil University of Medical Science, Ardabil, Iran

Received: 27 January 2020

Revised: 07 March 2020

Accepted: 17 March 2020

\section{*Correspondence:}

Dr. Afsaneh Enteshari Moghaddam,

Email: a.enteshari.m@arums.ac.ir

Copyright: (C) the author(s), publisher and licensee Medip Academy. This is an open-access article distributed under the terms of the Creative Commons Attribution Non-Commercial License, which permits unrestricted non-commercial use, distribution, and reproduction in any medium, provided the original work is properly cited.

\begin{abstract}
Background: Patent ductus arteriosus (PDA) is a common cause of morbidity and mortality among premature infants that affects more than $40 \%$ of them. PDA treatment includes medical and surgical treatment. Most drugs used to block PDA are cyclooxygenase inhibitors (ibuprofen and indomethacin). The role of paracetamol as an alternative therapy in PDA ligation has been considered in recent years due to the potential side effects of cyclooxygenase inhibitors.

Methods: Patients in the first group were treated with intravenous paracetamol at a dose of $15 \mathrm{mg} / \mathrm{kg}$ every 6 hours for three days and the second group was treated with intravenous ibuprofen at a daily dose of $10 \mathrm{mg} / \mathrm{kg} \mathrm{daily} \mathrm{and} 5 \mathrm{mg} / \mathrm{kg}$ for the second and third days. At the end of the treatment period (day 3), they underwent echocardiography again. If the echocardiographic findings indicated no closure of the arterial duct, patients were treated with the aforementioned drug for another period and rechecked at the end of the third day, and at each stage required information was collected.

Results: Arterial duct closure in paracetamol group was $96.7 \%$ and in ibuprofen group was $100 \%$. The effects of both paracetamol and ibuprofen were similar in terms of renal parameters but in terms of effects on liver parameters. The effect of paracetamol on all liver parameters except aspartate transaminase (AST) was significant, but ibuprofen was able to affect only bilirubin among liver parameters and had no significant effect on both AST and alanine aminotransferase, parameters.

Conclusions: Results showed that both paracetamol and ibuprofen are effective in treating of PDA and had similar impact.
\end{abstract}

Keywords: Ibuprofen, Paracetamol, PDA, Liver markers, Renal markers

\section{INTRODUCTION}

Patent ductus arteriosus (PDA) is a common cause of morbidity and mortality among preterm infants that involved more than $40 \%$ of them. There are several diseases that can be associated with PDA but it is not clear whether PDA has role in their producing or not. ${ }^{1,2}$ PDA treatment includes medical and surgical methods. Most of drugs are used to closure of PDA such as ibuprofen and indomethacin that often cyclo-oxygenase inhibitors that inhibit the conversion of arachidonic acid to prostaglandin., ${ }^{3,4}$ The success rate of PDA treatment with Ibuprofen has been reported in various studies in the range of $70-85 \% .^{5-8}$ Several complications include 
peripheral vaso-constriction, gastrointestinal bleeding and perforation, decreased platelet association, hyperbilirubinemia and kidney failure have been reported in these patients. ${ }^{9-12}$

In recent years the role of paracetamol (acetaminophen) as an alternative treatment in closure of PDA due to the potential effects of cyclooxygenase inhibitors has been considered. ${ }^{13-15}$ Some studies have shown that intravenous paracetamol can be replaced in patients with contraindication for given ibuprofen prescription. ${ }^{15}$ If non-steroidal anti-inflammatory drug (NSAID) are not successful in the treatment of PDA treatment or NSAID are controandice, the only available way was surgery that this surgery associated with risk of cardiothoracic surgery and neurologic complications. ${ }^{16}$ Therefore another drug intervention is needed. The aim of this study was to compare of the effect of two drugs paracetamol with intravenous ibuprofen in treatment of PDA.

\section{METHODS}

\section{Study design and participants}

This is a single-blind clinical trial that has been done from April 2018 to 2019 on 60 preterm infants with gestational age of 34-34 weeks who hospitalized in the NICU of Ardabil Bu-Ali and Alavi hospitals which have confirmed PDA in echocardiography.

\section{Inclusion and exclusion criteria}

Infants with life-threatening infections, with a urinary output of less than $1 \mathrm{ml} / \mathrm{kg} / \mathrm{h}$ over the past 8 hours, with serum creatinine levels above 1/88. 4 um, with platelet count less than 50000 per liter, hyperbilirubinemia requiring blood exchange, active necrotizing enterocolitis, liver dysfunction, retinopathy, gastrointestinal bleeding and parental dissatisfaction were excluded from the study.

\section{Data collection and sampling technique}

Patients were randomly divided into two groups each with 30 infants. Patients in the first group were treated with intravenous paracetamol at a dose of $15 \mathrm{mg} / \mathrm{kg}$ every 6 hours for three days and the second group was treated with intravenous ibuprofen at initial dose of $10 \mathrm{mg} / \mathrm{kg}$ daily and the second and third days were $5 \mathrm{mg} / \mathrm{kg}$. All infants go to echocardiography 24 hours later and if the echocardiography findings indicated no closure of the PDA, patients were treated with the drug for another period and rechecked by ECG at the end of the third day. Required information were recorded and collected at each stage. Complete blood count (CBC), bilirubin (Bili), blood urea nitrogen (BUN), creatinine (Cr), aspartate transaminase (AST), alanine aminotransferase (ALT), and cranial ultrasound examinations were performed before and 24 hours after drug administration and results were recorded in a checklist.

\section{Statistical analysis}

Data were analyzed by SPSS version 24 and T- test was used for relation between quantitative data and chi-square test for relation between qualitative data. Significance level was considered at less than 0.05 in all tests.

\section{RESULTS}

In this study, $50 \%$ of the samples were girls and $50 \%$ were boys. The lowest gestational age was 28 and the highest was 34 from and the age of neonates were from 1 to 3 days and the two groups were similar in terms of age. The size of the initial PDA varied from 1.3 to $4 \mathrm{~mm}$. Echocardiographic examination showed that PDA was $100 \%$ closed in the biboprofen group and $96.7 \%$ in the paracetamol group and the effect of both drugs on PDA closure was found to be same. Gastrointestinal bleeding complications were not observed in two groups. Cranial ultrasound was normal in both groups. There were no significant differences between the renal function indices before treatment and the first 24 hours after treatment among two groups (Table 1).

Regarding the changes in liver function indices before and also in the first 24 hours after treatment, it was found that there was no significant difference between the two groups and we could say that administration of either paracetamol or ibuprofen has not effects on neonatal liver function indices (Table 2).

Independent T-test show no significant changes in platelet level between the two groups before and after treatment (Table 3).

Results showed that in the paracetamol group, the platelet content decreased after treatment compared to pretreatment and in the ibuprofen group, platelet content increased but the difference was not statistically significant in two groups (Table 4).

Table 1: The amounts of renal performance indices in two groups.

\begin{tabular}{|c|c|c|c|}
\hline $\begin{array}{l}\text { Renal } \\
\text { indices }\end{array}$ & Groups & Mean \pm SD & $P$ value \\
\hline \multirow{2}{*}{$\begin{array}{l}\text { Cr before } \\
24 \text { hours }\end{array}$} & Paracetamol & $0.74 \pm 0.19$ & \multirow{2}{*}{0.68} \\
\hline & Ibuprofen & $0.78 \pm 0.4$ & \\
\hline \multirow{2}{*}{$\begin{array}{l}\text { Cr later } 24 \\
\text { hours }\end{array}$} & Paracetamol & $0.6 \pm 0.2$ & \multirow{2}{*}{0.57} \\
\hline & Ibuprofen & $0.6 \pm 0.3$ & \\
\hline \multirow{2}{*}{$\begin{array}{l}\text { BUN } \\
\text { before }\end{array}$} & Paracetamol & $22.3 \pm 9.8$ & \multirow{2}{*}{0.06} \\
\hline & Ibuprofen & $28.5 \pm 14.6$ & \\
\hline \multirow{2}{*}{$\begin{array}{l}\text { BUN } 24 \\
\text { hours later }\end{array}$} & Paracetamol & $19.5 \pm 8.4$ & \multirow{2}{*}{0.28} \\
\hline & Ibuprofen & $22 \pm 9.5$ & \\
\hline
\end{tabular}


Table 2: The amounts of liver performance indices in two groups.

\begin{tabular}{|llll|}
\hline $\begin{array}{l}\text { Liver } \\
\text { indices }\end{array}$ & Groups & Mean \pm SD & P value \\
\hline $\begin{array}{l}\text { Bilirubin } \\
\text { before }\end{array}$ & Paracetamol & $8.3 \pm 1.8$ & \multirow{2}{*}{0.28} \\
\cline { 2 - 3 } $\begin{array}{l}\text { Bilirubin 24 } \\
\text { hours later }\end{array}$ & Paracetamol & $7.8 \pm 2.2$ & \\
\cline { 2 - 3 } Abuprofen & $6.9 \pm 1.9$ & \multirow{2}{*}{0.37} \\
\hline $\begin{array}{l}\text { AST 24 } \\
\text { hours later }\end{array}$ & Paracetamol & $42.6 \pm 9.7$ & \multirow{2}{*}{0.71} \\
\cline { 2 - 3 } & Ibuprofen & $43.8 \pm 14.2$ & \\
\hline ALT before & Ibuprofen & $41.9 \pm 11.4$ & 0.69 \\
\cline { 2 - 3 } & Paracetamol & $16 \pm 3.8$ & \multirow{2}{*}{0.26} \\
\hline $\begin{array}{l}\text { ALT 24 } \\
\text { hours later }\end{array}$ & Paracetamol & $17.9 \pm 7.8$ & \\
\cline { 2 - 3 } & Ibuprofen & $16.9 \pm 4.2$ & \multirow{2}{*}{0.18} \\
\hline
\end{tabular}

Table 3: The amounts of platelet in two groups.

\begin{tabular}{|llll|}
\hline Time & Groups & Mean \pm SD & P value \\
\hline \multirow{2}{*}{ Before } & Paracetamol & $285300 \pm 39270$ & \multirow{2}{*}{0.08} \\
\cline { 2 - 3 } & Ibuprofen & $259640 \pm 66754$ & \\
\hline $\begin{array}{l}\text { 24 hours } \\
\text { later }\end{array}$ & Paracetamol & $273700 \pm 30315$ & \multirow{2}{*}{0.38} \\
\cline { 2 - 3 } & Ibuprofen & $289280 \pm 92760$ & \\
\hline
\end{tabular}

Results showed that among paracetamol recipients the rate of changes in $\mathrm{Cr} / \mathrm{BUN} /$ bilirubin/ALT after treatment significantly higher than before but for the AST index these changes were not significant (Table 5).

Results showed that among ibuprofen recipients, the rate of BUN/Cr/Bili changes after treatment was significantly higher than before but for ALT and AST indices this difference was not significant (Table 6).

Table 4: The changes of platelet indices in two groups by time.

\begin{tabular}{|c|c|c|c|c|}
\hline Drugs & Groups & Mean \pm SD & Mean diff & P value \\
\hline \multirow{2}{*}{ Paracetamol } & Before & $285300 \pm 39270$ & \multirow{2}{*}{11600} & \multirow{2}{*}{0.12} \\
\hline & 24 hours later & $273700 \pm 30315$ & & \\
\hline \multirow{2}{*}{ Ibuprofen } & Before & $259640 \pm 66754$ & \multirow{2}{*}{-29620} & \multirow{2}{*}{0.08} \\
\hline & 24 hours later & $289280 \pm 92760$ & & \\
\hline
\end{tabular}

Table 5: The changes of experimental indices in paracetamol group by time.

\begin{tabular}{|c|c|c|c|c|}
\hline Indices & Groups & Mean \pm SD & Mean diff & $P$ value \\
\hline \multirow{2}{*}{$\mathrm{Cr}$} & Before & $0.74 \pm 0.19$ & \multirow[t]{2}{*}{0.14} & \multirow[t]{2}{*}{0.001} \\
\hline & 24 hours later & $0.6 \pm 0.2$ & & \\
\hline \multirow{2}{*}{ BUN } & Before & $22.3 \pm 9.8$ & \multirow[t]{2}{*}{2.8} & \multirow[t]{2}{*}{0.001} \\
\hline & 24 hours later & $19.5 \pm 8.4$ & & \\
\hline \multirow{2}{*}{ Bili } & Before & $8.3 \pm 1.8$ & \multirow[t]{2}{*}{0.5} & \multirow[t]{2}{*}{0.002} \\
\hline & 24 hours later & $7.8 \pm 2.2$ & & \\
\hline \multirow{2}{*}{ AST } & Before & $42.6 \pm 9.7$ & \multirow[t]{2}{*}{1.8} & \multirow[t]{2}{*}{0.07} \\
\hline & 24 hours later & $40.8 \pm 10.6$ & & \\
\hline \multirow{2}{*}{ ALT } & Before & $16 \pm 3.8$ & \multirow[t]{2}{*}{1.1} & \multirow[t]{2}{*}{0.016} \\
\hline & 24 hours later & $14.9 \pm 4.2$ & & \\
\hline
\end{tabular}

Table 6: The changes of experimental indices in ibuprofen group by time.

\begin{tabular}{|lllll|}
\hline Indices & Groups & Mean \pm SD & Mean diff & P value \\
\hline \multirow{2}{*}{ Cr } & Before & $0.78 \pm 0.4$ & 0.18 & 0.001 \\
\cline { 2 - 4 } BUN & 24 hours later & $0.6 \pm 0.3$ & 6.5 & \multirow{2}{*}{0.005} \\
\hline \multirow{2}{*}{ Bili } & Before & $28.5 \pm 14.6$ & 0.9 & \multirow{2}{*}{0.008} \\
\hline \multirow{2}{*}{ AST } & Before & $22 \pm 9.5$ & 1.9 & \multirow{2}{*}{0.3} \\
\hline \multirow{2}{*}{ ALT } & 24 hours later & $6.8 \pm 2.2$ & 1 & \multirow{2}{*}{0.11} \\
\hline
\end{tabular}




\section{DISCUSSION}

The arterial canal is functionally closed in most term neonates on the first day of life and PDA is permanently abnormal.

Since $30-60 \%$ of infants with low birth weight, arterial canal remain open and spontaneous occlusion of this artery occurs only in one third of infants with less than $1000 \mathrm{~g}$ in the first four days of life, therefore a significant majority of these infants are potential candidates for drug or surgical interventions. ${ }^{17}$ One of the important topics in neonatal science is arterial closure methods. The findings of a recent study showed that the results of using oral acetaminophen were comparable to ibuprofen in PDA and both drugs had similar effect in PDA in preterm infants. Although the use of drugs such as indomethacin and ibuprofen are common medications but the side-effects and barriers to their use have always been of interest to experts in finding less effective drug therapies. So far, few studies have been conducted to evaluate the efficacy of ascetaminophen in the treatment of open artery and compare its efficacy with other drugs. In many cases, acetaminophen is also used as a complementary drug not as a first-line treatment in cases where COX inhibitors are ineffective or contraindicate has for their using. In the present study, there was no significant difference between the effect of intravenous ibuprofen and intravenous acetaminophen on PDA in preterm infants. The results of Dang et al study which compared the efficacy and safety of oral acetaminophen versus oral ibuprofen on 160 preterm infants (with gestational age less than 34 weeks) showed that both drugs were treated equally in the PDA $(81.2 \%$ vs. $78.8 \%)$. These results are consistent with the findings of our study. ${ }^{18}$

Results of evaluation of efficacy and safety of oral Acetaminophen versus oral Ibuprofen for the treatment of PDA in 90 premature infants with gestational age less than 30 weeks and birth weight less than $1250 \mathrm{~g}$ , which their PDA confirmed by ECG, showed that after the first treatment period, the PDA was closed in $77.5 \%$ of neonates receiving Ibuprofen and $72.5 \%$ of neonates receiving acetaminophen. The researchers concluded that oral acetaminophen could be a good alternative to the treatment of PDA in premature infants. ${ }^{19}$ Based on the study by Sinha et al as well as the study by Trerien et al acetaminophen, compared to ibuprofen can be a safe and promising drug for the treatment of PDA in premature infants with PDA. ${ }^{20-21}$ Yorotouten et al also evaluated and treated six premature infants with PDA with oral Acetaminophen suggesting that acetaminophen has the low side effects and low cost and had efficacy than other drugs in treatment of PDA. This result is also in line with the findings of our study. ${ }^{22}$ A study conducted at Qazvin university of medical sciences in 2007 aimed to compare the effect of oral ibuprofen with oral acetaminophen on the closure of PDA in preterm infants also suggested paracetamol as a suitable alternative to ibuprofen. ${ }^{17}$ Zasel et al also concluded that there was no significant difference between the two drugs paracetamol and ibuprofen in the PDA treatment. ${ }^{23}$ Overall, paracetamol seems to be a good alternative to ibuprofen. According to the results of this study, there was no gastrointestinal bleeding and platelet loss induced by ibuprofen. According to a study by Dung et al which compared the efficacy and safety of oral acetaminophen versus oral Ibuprofen in 160 premature infants (with gestational age less than 34 weeks), hyperbilirubinemia or gastrointestinal bleeding in the acetaminophen group was somewhat lower than ibuprofen. ${ }^{18}$ In this study, no differences were found in other side effects or problems between the two groups. According to the results of the study by Sinha et al unlike Ibuprofen which had many side effects, no side effects were observed after oral acetaminophen administration. ${ }^{20}$ According to the results of the study by Treiean et al although neonatal treatment with ibuprofen or indomethacin produced many adverse effects but no adverse effects or serious problems were observed during treatment with acetaminophen. The results of these studies were similar to our study results. ${ }^{21}$

\section{CONCLUSION}

Results showed that PDA closure rate was higher in ibuprofen recipients' groups $(100 \%)$ than in paracetamol recipients $(96.7 \%)$ but this difference was not statistically significant. We could say that both ibuprofen and paracetamol drugs were effective in treating PDA and can be used interchangeably. Gastrointestinal bleeding and platelet loss were not observed in this study among two groups. It is suggested that a larger sample size study be conducted in other centers and provinces in the future.

\section{Funding: No funding sources \\ Conflict of interest: None declared}

Ethical approval: The study was approved by the Ardebil University of Medical Sciences Ethics Committee with code IR.ARUMS.REC.1397.220

\section{REFERENCES}

1. Strauss T, Pessach I, Jacoby E, Eisen SI, Mazkereth R, Kuint J. Carina angle measurements for diagnosis of patent ductus arteriosus in preterm infants. Neonatology. 2011;99:224-30.

2. Overmeire BV, Chemtob S. The pharmacologic closure of the patent ductus arteriosus. In Seminars in Fetal Neonatal Med. 2005;10;177-84.

3. Noori S. Patent ductus arteriosus in the preterm infant: to treat or not to treat. J Perinatol. 2010;30:31.

4. Demirel G, Erdeve O, Dilmen U. Pharmacological management of PDA: oral versus intravenous medications. Current Clin Pharmacol. 2012;7:263-70.

5. Erdeve O, Yurttutan S, Altug N, Ozdemir R, Gokmen $\mathrm{T}$, Dilmen U, et al. Oral versus intravenous ibuprofen for patent ductus arteriosus closure: a randomised controlled trial in extremely low birthweight infants. 
Arch Dis Childhood-Fetal Neonatal Edition. 2012;97:279-83.

6. Gokmen T, Erdeve O, Altug N, Oguz SS, Uras N, Dilmen U. Efficacy and safety of oral versus intravenous ibuprofen in very low birth weight preterm infants with patent ductus arteriosus. J Pediatr. 2011;158:549-54.

7. Oncel MY, Yurttutan S, Degirmencioglu H, Uras N, Altug N, Erdeve O. Intravenous paracetamol treatment in the management of patent ductus arteriosus in extremely low birth weight infants. Neonatol. 2013;103:166-9.

8. Erdeve O, Gokmen T, Altug N, Dilmen U. Oral versus intravenous ibuprofen: which is better in closure of patent ductus arteriosus. Pediatrics. 2009;123:763.

9. Zecca E, Romagnoli C, Carolis DMP, Costa S, Marra $R$, Luca D. Does ibuprofen increase neonatal hyperbilirubinemia. Pediatrics. 2009;124:480-4.

10. Erdeve O, Sarici SU, Sari E, Gok F. Oral-ibuprofeninduced acute renal failure in a preterm infant. Pediatr Nephrol. 2008;23:1565-67.

11. Green K, Drvota V, Vesterqvist O. Pronounced reduction of in vivo prostacyclin synthesis in humans by acetaminophen (paracetamol). Prostaglandins. 1989;37:311-5.

12. Lucas R, Warner TD, Vojnovic I, Mitchell JA. Cellular mechanisms of acetaminophen: role of cyclooxygenase. FASEB J. 2005;19:635-37.

13. Hammerman C, Nun BA, Markovitch E, Schimmel MS, Kaplan M, Fink D. Ductal closure with paracetamol: a surprising new approach to patent ductus arteriosus treatment. Pediatrics. 2011;128:1618-21.

14. Oncel MY, Yurttutan S, Uras N, Altug N, Ozdemir R, Ekmen S, et al. An alternative drug (paracetamol) in the management of patent ductus arteriosus in ibuprofen-resistant or contraindicated preterm infants. Arch Dis Childhood-Fetal Neonatal Edition. 2013;98:94-8.

15. Oncel MY, Yurttutan S, Degirmencioglu H, Uras N, Altug N, Erdeve O. Intravenous paracetamol treatment in the management of patent ductus arteriosus in extremely low birth weight infants. Neonatology. 2013;103:166-9.

16. Mandhan P, Brown S, Kukkady A, Samarakkody U. Surgical closure of patent ductus arteriosus in preterm low birth weight infants. Congenital Heart Dis. 2009;4:34-7.

17. Habibi M, Nobakht M, Yazdi Z, Jangjoo $T$. Comparison of oral ibuprofen versus acetaminophen in infants with patent ductus arteriosus in Kosar Hospital; Qazvin-Iran. Master's thesis, Qazvin University of medical sciences, Qazvin. Iran; 2016.

18. Dang D, Wang D, Zhang C, Zhou W, Zhou Q, Wu H. Comparison of oral paracetamol versus ibuprofen in premature infants with patent ductus arteriosus: a randomized controlled trial. PLoS One. 2013;8(11):77888.

19. Aikio O, Harkin P, Saarela T, Hallman M. Early paracetamol treatment associated with lowered risk of persistent ductus arteriosus in very preterm infants. $\mathbf{J}$ Matern Fetal Neonatal Med. 2014;27:1252-6.

20. Sinha R, Negi V, Dalal SS. An Interesting Observation of PDA Closure with Oral Paracetamol in Preterm Neonates. J Clin Neonatol. 2013;2:30-2.

21. Terrin G, Conte F, Scipione A, Bacchio E, Conti MG, Ferro R, et al. Efficacy of paracetamol for the treatment of patent ductus arteriosus in preterm neonates. Ital J Pediatr. 2014;40:21.

22. Yurttutan S, Oncel MY, Arayici S, Uras N, Altug N, Erdeve O, et al. A different first-choice drug in the medical management of patent ductus arteriosus: oral paracetamol. J Matern Fetal Neonatal Med. 2013;26:825-7.

23. Zacel MY, Yurttutan S, Erdeve O, Uras N, Altug N, Oguz SS. Oral paracetamol versus oral ibuprofen in the management of patent ductus arteriosus in preterm infants: a randomized controlled trial. J Pediatr. 2014;164:510-4.

Cite this article as: Mirzarahimi M, Emamzadeghan R, Enteshari Moghaddam A, Falsafi N. Comparison of the effect of two drugs paracetamol with intravenous ibuprofen in patent ductus arteriosus treatment. Int J Basic Clin Pharmacol 2020;9:690-4. 